
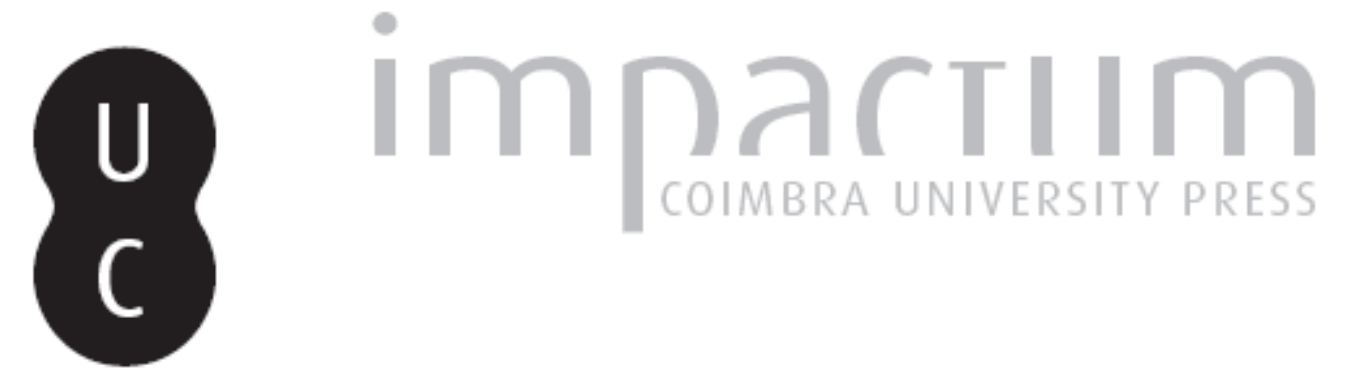

\title{
Ética e estética na música grega: a educação e o ideal da kalo-kagathía
}

\section{Autor(es): $\quad$ Cerqueira, Fábio Vergara}

Publicado por: Sociedade Brasileira de Estudos Clássicos

URL persistente:

URI:http://hdl.handle.net/10316.2/35798

DOI:

DOI:http://dx.doi.org/10.14195/2176-6436_24_5

Accessed : $\quad$ 26-Apr-2023 13:06:28

A navegação consulta e descarregamento dos títulos inseridos nas Bibliotecas Digitais UC Digitalis, UC Pombalina e UC Impactum, pressupõem a aceitação plena e sem reservas dos Termos e Condições de Uso destas Bibliotecas Digitais, disponíveis em https://digitalis.uc.pt/pt-pt/termos.

Conforme exposto nos referidos Termos e Condições de Uso, o descarregamento de títulos de acesso restrito requer uma licença válida de autorização devendo o utilizador aceder ao(s) documento(s) a partir de um endereço de IP da instituição detentora da supramencionada licença.

Ao utilizador é apenas permitido o descarregamento para uso pessoal, pelo que o emprego do(s) título(s) descarregado(s) para outro fim, designadamente comercial, carece de autorização do respetivo autor ou editor da obra.

Na medida em que todas as obras da UC Digitalis se encontram protegidas pelo Código do Direito de Autor e Direitos Conexos e demais legislação aplicável, toda a cópia, parcial ou total, deste documento, nos casos em que é legalmente admitida, deverá conter ou fazer-se acompanhar por este aviso.

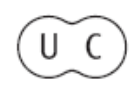




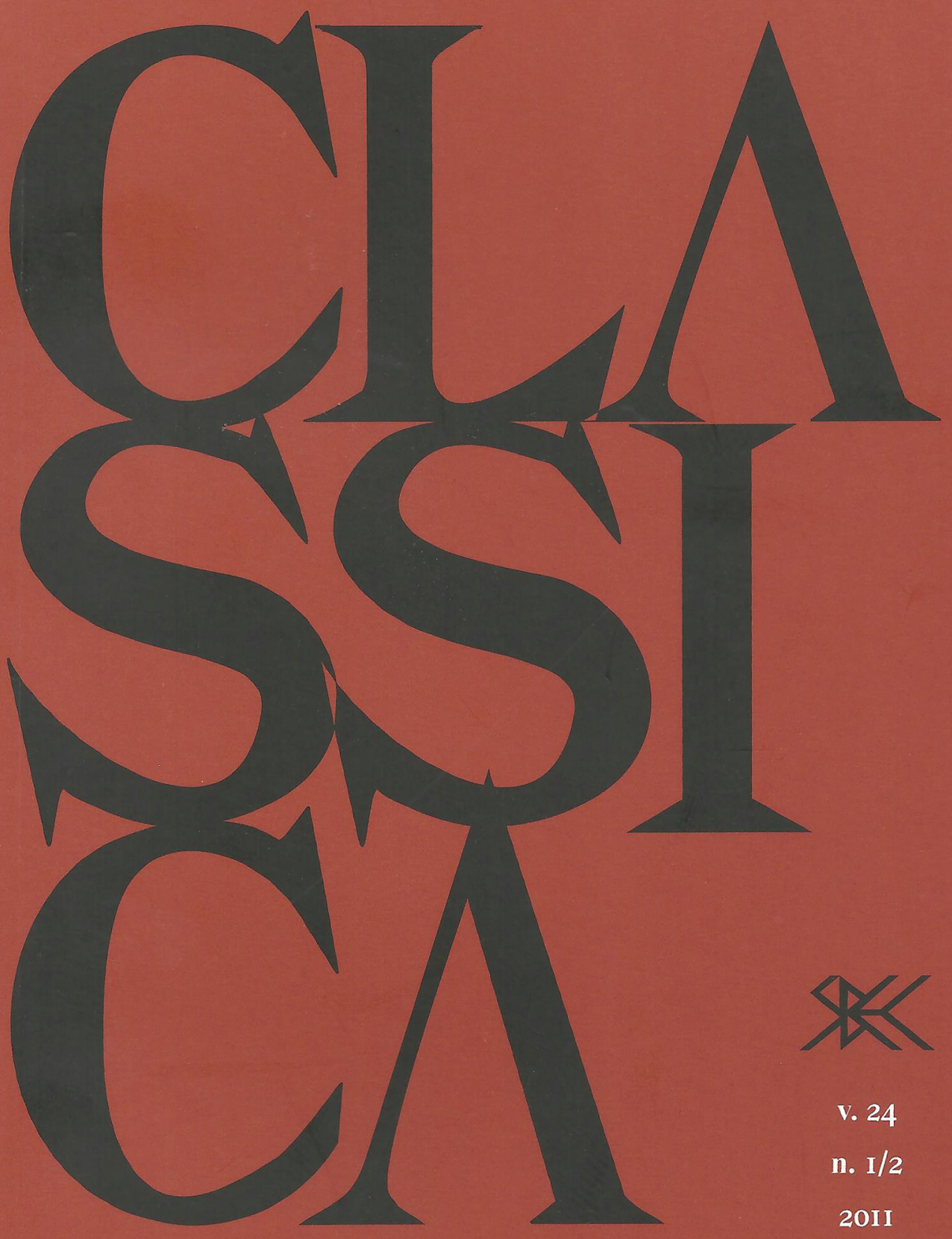




\title{
Ética e estética na música grega: a educação e o ideal da kalo-kagathía
}

\author{
Fábio Vergara Cerqueira \\ Universidade Federal de Pelotas
}

Resumo. Ética e estética são duas dimensões absolutamente imbricadas no pensamento musical grego. Os princípios morais contidos, por exemplo, na teoria do éthos musical norteiam a apreciação das formas musicais, seja no que se refere à escolha dos instrumentos, dos gêneros, ou dos modos musicais (escalas). A importância que os gregos conferiam a esta intersecção entre a estética e a ética na música assumia grande relevância política, como pode ser verificado no destaque dado à educação musical. Ao avaliar a biografia dos principais homens públicos atenienses, recorrendo-se a obras como as Vidas Paralelas de Plutarco, constata-se o quanto se valorizava a influência da formação musical sobre as qualidades políticas e morais de um cidadão. Consideravase que a música desempenhava importante papel para a constituição da virtude da kalo-kagathía (beleza-bondade), que era considerada o bem maior para um cidadão: o reconhecimento do belo e de escolha do bom, do justo. Vê-se, assim, a existência de uma pedagogia política, calcada nas noções de ética e estética, na qual o ensino musical merecia bastante atenção, como demonstram as recomendações de Platão e Aristóteles.

Palavras-chave. Grécia antiga; música; educação; ética; estética.

Ética e estética são duas dimensões absolutamente atreladas uma a outra no pensamento musical grego. Os princípios morais contidos, por exemplo, na teoria do éthos musical norteiam a apreciação das formas musicais, seja no que se refere à escolha dos instrumentos, dos gêneros,

Email: fabiovergara@uol.com.br

Instituto de Ciências Humanas, Departamento de História e Antropologia

Artigo adaptado a partir da comunicação homônima apresentada no simpósio temático "Ética e Estética no Mundo Antigo: cotidiano, cultura e sociabilidade", coordenado pelo autor e pela historiadora Dra. Regina Candido, como parte da programação oficial do XXV Simpósio Nacional História da ANPUH, realizado em Fortaleza, entre os dias 12 e 17 de julho de 2009, com a temática "História e Ética". Com outro enfoque, o mesmo tema foi abordado anteriormente na conferência intitulada 'Percepciones estéticas e valoraciones éticas del uso cotidiano de los instrumentos musicales en la Grecia antigua', apresentada no XI Encuentro Nacional de Estudios Clásicos 'La Idea de belleza en la antigua Hélade', realizado em Santiago, entre 9 e 12 de agosto de 2005, constando dos anais do evento, publicados na coleção ITER Encuentros, vol. XIV, 2006. 
ou dos modos musicais (escalas). A importância que os gregos conferiam a esta intersecção entre a estética e a ética na música assumia grande relevância política, como pode ser verificado no destaque dado à educação musical. Ao avaliar a biografia dos principais homens públicos atenienses, recorrendo-se a obras como as Vidas Paralelas de Plutarco, constata-se o quanto se valorizava a influência da formação musical sobre as qualidades políticas de um cidadão. Considerava-se que a música desempenhava importante papel para a constituição da virtude da kalo-kagathía (beleza-bondade), que era considerada o bem maior para um cidadão: o sentido do reconhecimento do belo e de escolha do bom, do justo. Vêse, assim, a existência de uma pedagogia política, calcada nas noções de ética e estética, na qual o ensino musical merecia bastante atenção, como demonstram as recomendações de Platão e Aristóteles.

Na pintura de vasos atenienses, a mudança de paradigmas morais, do mundo aristocrático ao democrático, da ideologia bélica homérica à hoplítica - e essa transformação mental correspondia à afirmação institucional do universo políade -, a lýra parecia simbolizar o advento e garante dessa ordem. A lýra, em mãos de heróis tradicionalmente admirados pela sua força - por sua lýssa, por sua lança e seu escudo - é agora um atributo desta nova visão dos heróis sob a cultura da cidade democrática: ela os intelectualiza, contém sua hýbris, impõe uma medida, adequando-os à ideologia políade. Charles Dugas e Jan Bazant analisam o sentido do Héracles mousikós ${ }^{1}$ como uma progressiva tendência de intelectualização do herói. Para Bazant ${ }^{2}$, na crescente predileção pelos temas da apoteose de Héracles e de Héracles mousikós, desde o final do século VI, pode ser identificada uma analogia: o herói que troca a lança e escudo pela cítara é o mesmo que ascende ao Olimpo, para o eterno convívio dos deuses. Esses temas representam uma visão moralista de Héracles, bem acabada no séc. IV, que foi a solução encontrada para resolver a incompatibilidade entre a democracia emergente nas primeiras décadas do séc. V - com seu respectivo sentido de koinonía - e um herói que era louvado por qualidades aristocráticas, individuais. Grosso modo, o Héracles guerreiro implicava hýbris (constituindo um perigo simbólico para a democracia) ${ }^{3}$; o Héracles mousikós, em companhia dos deuses, significava sōphrosýnē.

${ }^{1}$ Ânfora. 520-510. Antigamente na Basiléia (hoje no comércio) Phot. D. Widmer 5992. LIMC Athena 617. Cena musical: Héracles kitharōidós com Atena aulētrís.

2 J. Bazant, 'Herakcles and Athenian Hoplites', in Studies on the Use and Decoration of Athenian Vases, Praga, Nakladatelstvi Ceskoslovenske Akademie Ved, 1981, p. 31, fig, 8,18.

${ }^{3}$ J. BAZANT, p. 26-30. 
Assim, o Héracles citaredo simbolizava o cidadão da pólis democrática, com uma formação que lhe tornava apto ao bom exercício das funções públicas, bastante diferente daquele Héracles do início do séc. V, arredio à música, o qual matou seu professor de lýra, Linos.

Temos aqui uma série de noções correlatas acerca da lýra: intelectualiza heróis violentos e bravios, tornando-os mais comedidos, temperantes; controla as paixões arrebatadoras e os temperamentos irascíveis; arrefece o moral e apazigua as quizilas.

O canto do citaredo Orfeu, a esse respeito, é paradigmático. Dizia-se que tocava com tanta perfeição, que árvores e rochedos deixavam seus lugares, os rios suspendiam as suas correntes, e as feras concorriam em tropel ao redor dele para escutá-lo. Com o acorde de sua lýra, enternecera Plutão, convencendo-o a devolver-lhe sua mulher Eurídice (Ap. Rhod. Argon. 1.42). Dizia-se, também, que sua melíflua voz e sua terna lýra encantavam os soldados trácios, contendo a violência de sua barbárie.

Estas significações civilizadoras associadas à música integram-na aos alicerces da vida políade. Daí deriva o grande prestígio desfrutado pela educação musical na formação dos cidadãos.

\section{A educação musical nas biografias de políticos gregos proeminentes}

Estudando-se biografias dos principais homens de Estado atenienses do período clássico verificamos a importância conferida por muitos cidadãos ao aprendizado musical ${ }^{4}$. Tomemos por exemplo as Vidas $\mathrm{Pa}$ ralelas de Plutarco, e analisemos as informações referentes ao período de formação, na infância e juventude, dos importantes homens públicos gregos e romanos estudados pelo biógrafo-historiador. A algumas constatações podemos chegar.

Numa comparação superficial, há referências à presença da música na formação de muitos homens públicos gregos; porém, no que se refere aos romanos, Plutarco não se preocupa em falar sobre a educação musical. É possível que os educadores romanos pensassem como Epicuro, para quem a música não tinha qualquer significado além de um jogo de sons, e concordassem com Cícero, que afirmava 'que a música não tem utilidade alguma além de um prazer infantil, sem valor nenhum, posto que não pode guiar-nos à felicidade'. ${ }^{5}$ Segundo o autor romano Cornélius Nepos, do séc. I d. C., 'ninguém ignora que a música, segundo o estado

\footnotetext{
${ }^{4}$ A. Bélis. Les musiciens dans l’Antiquité, Paris, Hachette, 1999, p. 16.

${ }^{5}$ K. SACHS, La musica en la Antigüedad, Barcelona, Labor, 1934. p. 98. BÉLIS, p. 16.
} 
de nossos costumes, não convém a um personagem importante', apesar de ter sido levada, entre os gregos, como 'digna de consideração e estima'. ${ }^{6}$

Conforme Plutarco, Alcibíades, na idade de estudos, ouvia os professores com atenção e, apesar de se recusar a aprender o aulós, aceitava dedicar-se à lýra e ao plêktron (Plut. Alc. 2); Nícias, por sua vez, não só recebera formação musical, como educara o jovem Hieron nas letras e na música (Plut. Nic. 5). Diferentemente do musical Nícias, cujas qualidades públicas eram admiradas, Címon, considerado desequilibrado e pouco habilidoso para a fala, não aprendeu nem a música nem as artes em voga entre os gregos (Plut. Cim. 4). Já Temístocles, segundo o biógrafo, era preguiçoso e desinteressado em relação aos estudos, apesar do talento reconhecido por seu mestre, que afirmou que ele jamais seria um qualquer, mas por certo grande no bem e no mal. Temístocles possivelmente tinha hábitos rudes, que justificavam as pilhérias que recebia das pessoas ditas cultas e refinadas, uma vez que ele não sabia manejar a lýra ou a kithára; ele retorquia, em contrapartida, que sabia tornar grande e ilustre uma cidade pequena e obscura. Alguns políticos atenienses que foram criticados por sua vida pública foram caracterizados por Plutarco como desprovidos de educação musical: assim, Cleon era acusado de incapacidade musical, afirmando-se que sequer podia afinar corretamente uma lýra. Fora do contexto ateniense, outro grande homem público que foi notabilizado pelos textos antigos por suas qualidades musicais foi o general tebano Epaminondas, que tocava lýra com perfeição (Plut. Nic. 5). Os casos expostos acima demonstram como, feita a ressalva do caso de Temístocles, devidamente destacada exatamente por chamar a atenção por se opor a uma regra presumível, para Plutarco possuir uma boa educação musical é uma condição sine qua non para ser um bom cidadão.

Vale lembrar que Plutarco, mesmo pensando de forma semelhante a Pitágoras, Platão e Aristóteles no que concerne a educação musical, deu voz a opiniões divergentes, que nutriam preconceitos em relação aos que se dedicam à música.

\footnotetext{
${ }^{6}$ Cit. in BéLIS, p. 16.

${ }^{7}$ Bélis, p. 16. P.C. CorrêA, Harmonia. Mito e música na Grécia Antiga. Coleção Letras Clássica, São Paulo, Humanitas (FFLCH/USP), 2003, p. 79-80: "Mas sobretudo, admirase isso / da sua musicalidade suína: / pois dizem os outros / meninos, colegas seus, / que apenas na harmonia dórica, ele / conseguia a lýra afinar; / outra, não queria aprender. / Então o mestre de cítara, / irado, mandou-o embora: / "Pois nenhuma outra harmonia este menino / é capaz de aprender, / senão a dolodórica (sic.)." (Cf. Ar. Eq. vv. 985-96, trad. Paula da Cunha Corrêa)
} 


\section{O controle ético-estético da educação musical para a formação do caráter do cidadão}

Plutarco nos permite visualizar a existência, na cultura grega, de aspectos controversos acerca do valor do ensino musical. A leitura do Livro VIII da Política de Aristóteles nos possibilita perceber, do mesmo modo, elementos de uma discussão pedagógica. O objetivo central desse trecho da obra aristotélica - que nos permite entender o porquê da inserção de uma reflexão sobre música num tratado dedicado à política - é defender a importância da música para a formação do caráter do cidadão, em oposição àqueles que acreditavam que ela levava à efeminação, malemolência e fraqueza de espírito. Aristóteles lembra que as melodias de Olimpos, compositor frígio do século VII, cuja existência pende mais para o lendário que para o histórico, enchem a alma de entusiasmo, que é uma emoção da parte ética da alma. 'Ora, os ritmos contêm representações de cólera e de doçura, e também de coragem e de moderação e de todos os sentimentos antagônicos e de qualidades morais, correspondentes com mais aproximação à verdadeira natureza destas qualidades' (Arist. Pol. 8.5).

Aristóteles acredita que a música contenha em si mesma a imitação das afecções do caráter, de forma que diferentes melodias imitam distintos tipos de caráter. O jovem, ao ser encaminhado para o aprendizado da música, deve entrar em contato com as melodias que imitam o caráter que se deseja do cidadão (livre, temperante, comedido, corajoso e viril), que são produzidas principalmente pelas melodias que portadoras do éthos praktikón ou do éthos ethikón ${ }^{8}$.

Aristóteles (Pol. 8.7) recomenda uma série de cuidados para se evitar que o estudo da música leve à efeminação, à covardia ou à fraqueza de caráter. Deve-se definir o grau de participação na execução musical dos meninos, evitando que eles continuem a tocar quando atingem idade adulta. Devem-se definir os ritmos e melodias adequadas à formação do jovem, preferindo-se aquelas compostas em modo dórico, pois este é 'mais calmo e de caráter mais viril. Além disso, já que elogiamos o meio termo e não os extremos, e dizemos que o primeiro deve ser preferido, e que o modo dórico é desta natureza em relação às outras harmonias, convém evidentemente que as melodias dóricas sejam usadas na educação dos alunos' (1342b). Devem-se definir os instrumentos empregados no aprendizado musical, preferindo-se a lýra ao aulós, uma vez que a primeira favorece o desenvolvimento da inteligência e o segundo não

${ }^{8}$ F.V. Cerqueira, Argumentos aristotélicos em favor do ensino musical: Política, VIII, Dissertatio. Revista de Filosofia da UFPEL, Pelotas, 3, 79-88, 1996. 
possui função moralizante, além de impedir o uso da fala e deformar o rosto durante a execução.

Temos muito mais testemunhos literários elaborados das opiniões favoráveis ao ensino da música do que das contrárias a ele, apesar das inúmeras passagens que indicam um preconceito em relação à delicadeza e refinamento promovidos pela educação musical. De uma forma dispersa, essas ideias contrárias ao ensino musical estavam expressas no pensamento dos cínicos, como Antístenes, e, de forma mais clara, em Epicuro.

Havia então um intenso debate pedagógico, entre aqueles, como Pitágoras, Platão e Aristóteles, que acreditavam no valor do ensino musical, e aqueles outros, como Filipe II, Antístenes e Epicuro, que desconfiavam da capacidade da música de qualificar o caráter do cidadão. Um dos focos centrais deste debate estava no valor educativo e político atribuído aos instrumentos musicais.

\section{O valor educativo e político da música e dos instrumentos musicais}

Sotérichos, personagem do tratado dialógico De Musica, de Plutarco, propugnava o valor educativo do aulós, como base de uma sólida formação musical. Alguns séculos antes, o general e político tebano Epaminondas, falecido 362 a.C., famoso por tocar cítara com perfeição, o que contaria na formação de seu elogiável caráter como homem público, recebeu também ensinamento de dança e de aulós.

A capacidade apaziguadora, tradicionalmente atribuída à lýra, era, em Tebas, associada ao aulós. Segundo Plutarco, 'com a intenção de acalmar e adoçar desde a infância a impetuosidade e a dureza da índole dos seus compatriotas, os legisladores tebanos introduziram por tudo, nas ocupações sérias como nos divertimentos, o uso do aulós, ao qual atribuíram honra e distinção' (Plut. Pel. 19.1). ${ }^{9}$

Na mesma direção, a tradição narra o papel da arte do aulós de Taletas de Creta e, sucessivamente, de Tirteu, na segunda katástasis de Esparta, na qual a música do aulós desempenhou uma função atribuída com mais freqüência à lýra, a função apaziguadora, de harmonizadora dos contrários, enfim, a função política. ${ }^{10}$

\footnotetext{
${ }^{9}$ P. Roesch, 'Famiglie di auleti in Beozia', in D. Restani (org.), Musica e mito nella Grecia antica, Bolonha, Il Molino, 1995, p. 126, nota 5.

${ }^{10}$ A. Gostoli, 'Terpandro e la funzione etico-politica della musica nella cultura spartana del VII sec. a.C.', in B. Gentili e R. Pretagostini, La musica in Grecia, Roma-Bari, Laterza, 231-7, 1988. Na verdade, as fontes deixam uma margem de incerteza quanto ao verdadeiro nome, Taletas ou Tales, e quanto a seu instrumento, a lýra ou o aulós; quanto
} 
Platão e Aristóteles, por sua vez, concordam na condenação ao aulós. O primeiro propunha, em sua utopia, que os aulètai fossem expurgados de sua cidade ideal, porquanto possuía seu instrumento a maior quantidade de sons, podendo-se nele executar todas as tonalidades ${ }^{11}$. Asseverava que se preferisse 'Apolo e os instrumentos de Apolo (a lýra) a Mársias com os dele (aulós)' (Pl. Resp. 3.399d). Aristóteles, de sua parte, alertava que, para se impedir que a educação musical levasse à vulgaridade - evitando o amesquinhamento do corpo, ao inutilizá-lo para as atividades marciais e cívicas do cidadão -, não se devia admitir o aulós, pois esse 'não exercia função moralizante, mas apenas excitante’ (Arist. Pol. 8.6.1341b).

A lýra, por sua vez, era vista como o instrumento nacional por excelência (Plut. De Mus. 3). Era assimilada como o instrumento que simbolizava a cultura e a excelência dos antigos. Deuses olímpicos e heróis homéricos dedicavam-se a ela. Como o colocam acertadamente Martha Maas e Jane McIntosh Snyder, a relação intrínseca da lýra com Hermes e Apolo conotam seu valor educativo:

A história da invenção da lýra por Hermes e sua sucessiva transmissão para Apolo, como ressarcimento pelo gado roubado, reflete talvez o papel educativo do instrumento. Ambos os deuses são associados à formação e ao crescimento dos jovens rapazes, como sugerem diversos elementos, entre os quais a presença das hermas (pilastras fálicas encimadas por um busto de Hermes) nos ginásios, e o patrocínio de Apolo nos certames atléticas e culturais que ocorriam durante os Jogos Píticos de Delfos. ${ }^{12}$

\section{A institucionalização da educação musical: o programa pedagógico de ensino escolar ${ }^{13}$}

A educação na Grécia era, em princípio, relegada à iniciativa privada, exceção feita a algumas cidades no período helenístico, que insti-

à sua proveniência, porém, todos concordam: Gortyna, em Creta. Conforme Plut. De Mus. 10.1134d, seu nome seria Taletas e seu instrumento o aulós; segundo Plut. Lyc. 4, seu nome seria Tales e seu instrumento a lýra; em Pausânias 1.14.4, seu nome é Tales e seu instrumento não é lembrado. Conforme Plutarco, Taletas desenvolveu seus ritmos a partir de música para aulós de Olimpos. Posteriormente, porém, músicos que identificamos indubitavelmente com aulètaí, como Polymnestos de Cólofon e Sacadas de Argos, desempenharam também papel semelhante, contribuindo com sua música ao restabelecimento da ordem em Esparta (Plut. De Mus. 9.113b-c).

${ }^{11}$ CORrÊA, p. 72-3.

${ }^{12}$ M. MAas, J.M. Snyder, 'Strumenti a corde per dei e mortali', in D. Restani (org.), Musica e mito nella Grecia antica, Bolonha, Il Molino, 7-35, 1995.

${ }^{13}$ Os conceitos trabalhados nesta sessão foram objeto de análise em: CerqueIRA, F. V. 
tuíram um sistema financiado pela pólis. Via de regra, freqüentavam as escolas os meninos cujos pais tinham condições financeiras para pagar pelos serviços dos professores, que eram responsáveis pelo empreendimento (instalações escolares, sediadas em uma palestra, ginásio, ou na própria casa do mestre). No entanto, desde o final do século $\mathrm{V}$ é comum que filósofos, tais como Platão, tenham reclamado por um forte controle sobre a educação, sobretudo sobre a matriz curricular. Fato é que a educação, mesmo sendo iniciativa particular, sempre esteve sob forte controle da comunidade políade, que nunca entregou ao "mercado" a decisão sobre a rotina escolar e sobre os ensinamentos. A pólis legislou sobre o funcionamento do ensino e atribuiu função pública a magistrados, escolhidos pela Assembléia, ou fiscais, nomeados pela Boulê, que deviam zelar pela formação escolar dos jovens cidadãos. ${ }^{14}$

$\mathrm{Na}$ escola tradicional, estabelecida no final do período arcaico, ensinavam-se ao jovem a música e a ginástica (Pl. Criti. 50d). Somente mais tarde foram incorporados outros ensinamentos, que incluíam escrita, literatura e matemática. O menino de condição livre, filho de cidadão, devia freqüentar uma escola, pois isso o ajudava a se projetar, quando adulto, na comunidade de cidadãos, conferindo-lhe ao mesmo tempo status e qualificação. Em Atenas, os rapazes assistia à aula de música dos 13 aos 16 anos de idade (Pl. Leg. 7.810a, 812d). Uma fonte tardia nos fornece uma rara descrição do mundo do menino, em oposição ao mundo da menina, colocando os objetos escolares, "reverenciados como instrumentos da virtude", como uma característica distintiva, em oposição ao pente e ao espelho. A identidade social do menino, do ponto de vista da cultura material, está vinculada aos instrumentos pedagógicos que lhe proporcionam tornar-se um kalós-kagathós: as “tabuinhas e rolos que preservam o

'Educação, Música e Política na Grécia Antiga', in T. Oliveira. (Org.), Educação, História e Filosofia no Ocidente: Antiguidade e Medievo, 1 ed., Itajaí, Univali Editora, 69-92, 2009. ${ }^{14}$ Uma inscrição do séc. II a.C. revela a regulamentação estabelecida para o funcionamento de um ginásio na cidade macedônica de Beroia. Além de disciplinar sobre as categorias etárias com que os freqüentadores se dividem, proíbe os contatos entre adultos jovens (20 a 30 anos) com os efebos (18 a 20) e paîdes (12 ou 14 a 18), visando talvez a evitar os contatos eróticos; proíbe ainda que se aproximem do ginásio escravos, libertos, deficientes visuais, prostituídos, bêbados e loucos; preconiza a atuação do gimnasiarca na organização das festa de Hermes, na escolha dos juízes para as competições que devem se realizar durante essa festa e a cada 4 meses, quando os alunos devem competir entre si; estabelece ainda os castigos físicos e multas àqueles que desrespeitarem às ordens do gimnasiarca, que deveria ser um respeitável cidadão de 30 a 60 anos de idade. Essa inscrição retrata um universo macedônico que não é exatamente o mesmo de Atenas, mas que guarda porém muitas semelhanças. 
mérito dos antigos feitos, juntamente com uma harmoniosa lýra, da qual ele precisava para ir ao mestre de música" (Pseudo-Luciano Amores 44).

O professor exercia sobre o aluno uma autoridade de repressão, no caso dele não corresponder plenamente aos ensinamentos (Pl. Euthyd. 295d, Ael. VH 3.32). O mito narrou o triste desfecho da atitude de Linos, quando tomou a iniciativa de reprimir Héracles, que mostrava ser um aluno relapso. Afora histórias como a de Alcibíades, que desobedece ao seu professor negando-se aprender aulós, os textos não nos revelam a insolência de garotos desobedientes.

A música não era o único conteúdo ensinado nas escolas - além da ginástica, ensinavam-se matérias tidas como secundárias com relação às primeiras: aprendia-se a recitar poemas decor, a ler e escrever; recebiamse ainda ensinamentos básicos de matemática e geometria. Todavia, a escola era também um lugar de convivência, onde os jovens permaneciam do amanhecer ao final do dia, lembrando as atuais escolas de turno integral: lá desfrutavam de tempo livre, em que podiam se distrair, inclusive praticando música (Ael. VH 12.9).

A educação era vista como um assunto e como uma atividade pública, pois dela dependiam a estabilidade da pólis e a normalidade do sistema político, tanto quanto dependiam da participação dos cidadãos nas Assembléias, Conselho, Tribunais e magistraturas. Compreendemos, assim, por que motivo havia sido instituída, por lei, a obrigatoriedade do ensino musical (Cf. Pl. Criti. 50d-e). A educação era objeto de regulamentação, sendo considerada uma esfera fundamental da vida pública, uma vez que competia a ela assegurar a formação espiritual do futuro cidadão. Neste aspecto, nos valemos do testemunho de Ésquines:

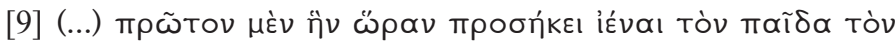

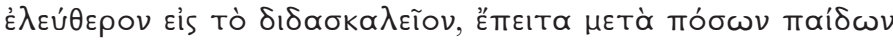

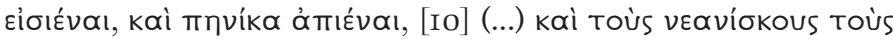

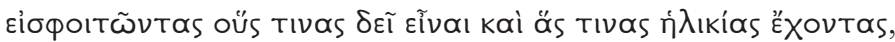

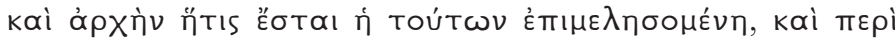

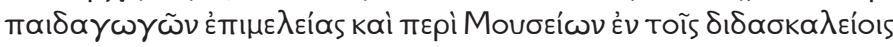

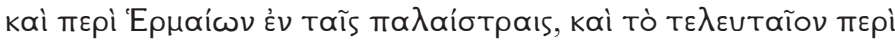

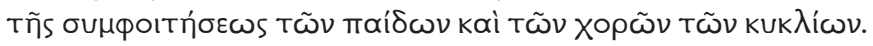

[9] (...) A lei fixa então exatamente a hora em que um menino de condição livre deve chegar à escola, o número de discípulos com os quais ele deve freqüentá-la, a hora em que deve partir. [10] (...) A lei diz também quais meninos podem freqüentar esses lugares, sua idade, e qual autoridade zelará pela execução do regulamento. A lei se ocupa também das funções dos escravos encarregados de acompa- 
nhar os meninos, da festa das Musas na escola, das festas de Hermes na palestra, e, enfim, da participação dos meninos nos coros cíclicos (Aeschin. In Tim. 9-10). ${ }^{15}$

Uma particularidade da mitologia grega são as narrativas sobre relações professor-aluno, presentes já nos poemas homéricos, com a incomum ocorrência de professores de música entre os heróis e deuses. Encontramos dois tipos de relação. O primeiro tipo marca uma relação propriamente de ensino, assumindo o papel de mitos que funcionam como paradigma da vida escolar. Quíron e Linos são de fato professores, respectivamente, de Aquiles e Heracles, aos quais ministram ensinamentos diversos. Note-se que, conforme o registro da iconografia dos vasos áticos, no séc. V a figura de Linos foi assimilada à função do kitharistếs, o professor de música, evidenciando a relação desta narrativa mítica com a realidade escolar.

O segundo tipo é de natureza amorosa, no qual a relação de troca de conhecimentos musicais confunde-se com a relação de troca erótica: Mársias é professor e amante de Olimpos, a quem ensina a tocar o aulós; situação semelhante envolve Pã, amante de Daphnis, que com ele aprende a soprar a syrinx.

Os dois tipos de relação professor-aluno que marcam o ensino musical nas narrativas míticas representam imaginariamente as duas dimensões envolvidas na prática social do ensino musical, em particular, e do ensino, em geral: a dimensão pedagógica e a dimensão homoerótica. De um lado, o aprendizado em si da música (juntamente à ginástica) como porta de entrada à cultura grega; de outro, as amizades homoeróticas, carregadas de sentido pedagógico na relação que liga erastếs e eroménos.

No caso de Atenas, os indícios são de que o professor de música não era arregimentado na elite local, diferentemente do que os testemunhos sugerem com relação a Mitilene (Alceu), no final do século VII, ou a Tebas (Mirtis), no século VI. Provavelmente, é na época de Sólon que aparecem os primeiros músicos atuando como professores em Atenas, a confiar no relato de Estobeu (Flor. 9.25). O legislador ateniense, ao defender as práticas dos ofícios assalariados por parte daqueles que passam dificuldades, sobretudo em atividades manuais e artesanais patroneadas por Hefesto e Atenas, inclui entre elas os ensinamentos nos dons das Musas olímpicas. Vemos então,

\footnotetext{
${ }^{15}$ Tradução livre a partir de: AEschines. Aeschines with an English translation by Charles Darwin Adams, Ph.D. Cambridge, MA, Harvard University Press; London, William Heinemann Ltd. 1919. Extraído de Perseus Digital Library, Gregory R. Crane, Editor inChief, Tufts University. < http://www.perseus.tufts.edu/hopper/text?doc=Perseus\%3Ate xt\%3A1999.01.0001\%3Aspeech\%3D1\%3Asection\%3D10. >
} 
aqui, o professor ser tratado como um tekhnitēs, incluído no mundo da técnica, junto a ferreiros e marceneiros, da mesma forma que os médicos.

No período clássico, a maioria daqueles que se tornaram líderes da política ateniense freqüentou um kitharistếs (professor de música). Os cidadãos que possuíam condições econômicas razoáveis, procuravam assegurar que seus filhos recebessem educação musical escolar. Um exemplo é Péricles, que estudou música com os professores Damon ou Pitóclides (Plut. Per. 4).

Na sua origem, a institucionalização da educação musical escolar ligava-se às antigas leis que tornaram obrigatório o ensino de música (Pl. Criti. 50d). As regulamentações públicas sobre o horário de funcionamento das escolas e sobre as restrições impostas aos jovens ${ }^{16}$, existentes no período clássico, demonstram a preocupação que a comunidade políade tinha com relação ao ensino musical como um dos aspectos fundamentais que envolvia a paideía dos jovens atenienses.

Regulamentavam que os meninos de condição livre deviam partir para a escola na alvorada; determinavam também o horário para retornar à casa, do mesmo modo como as disciplinas que deviam aprender; estabeleciam quais jovens podiam freqüentar as palestras e ginásios, bem como que idade deviam ter; definiam a autoridade que zelaria pela execução desse regulamento, e até as atribuições do paidagōgós; finalmente, regulamentavam as festividades das quais os meninos deviam participar (festa das Musas na escola, de Hermes na palestra e atuação nos coros cíclicos).

A educação escolar foi se tornando mais complexa e regrada com o passar do tempo. Na época de Platão, contavam-se já inúmeras autoridades educativas às quais o jovem devia se submeter até atingir o estatuto de cidadão: paidagōgós, grammatistếs, paidotríbēs, geômetra, instrutor militar, kosmētếs; gimnasiarca... O Areópago, mesmo depois de destituído de muitos de seus poderes, após as reformas de Efialtes em 461, continuou exercendo um papel importante no zelo da educação dos futuros cidadãos, tendo a incumbência de escolher alguns magistrados que atuavam como controladores da juventude (Pl. Ax. 366d-c). ${ }^{17}$

\footnotetext{
${ }^{16}$ Um exemplo de restrição imposta ao jovem (e futuro cidadão) diz respeito à prostituição. O Contra Timarco de Esquines é um testemunho paradigmático, pois a questão central da acusação que pairava sobre ele é que teria se prostituído na adolescência, o que lhe custaria a perda de seus direitos de cidadania.

${ }^{17}$ Diálogo apócrifo, escrito talvez por um peripatético. Alguns autores colocam-no ainda bem mais tarde. Citado por Diógenes Laércio, Clemente de Alexandria e Estobeu.
} 


\section{Reflexões finais: a educação musical e a kalo-kagathía}

Com que fim se desenvolveu o ensino musical escolar institucionalizado? Não foi para formar um músico profissional. Ensinava-se música na escola para inspirar a sabedoria e afastar o jovem do mau caminho. Pensavase que a música ajudaria a formar um cidadão bem educado espiritualmente para o exercício das funções públicas. Quando aprendia a tocar a lýra ( $\mathrm{ki}$ tharizein máthosin), a performance do jovem deveria se concentrar sobre os poetas líricos e as belas melodias. Assimilaria assim o conteúdo educador desses poemas, e, mais importante ainda, colocaria sua alma sob a égide do ritmo e da harmonia, de modo a se tornar apto à palavra e à ação (Pl. Prt. 326a, Aristid. Quint. 2.14, Arist. Pol. 8.5.1340b.11-13, Plut. De Mus. 26).

Formar um cidadão honesto. É para isso que se ensinava o canto e os instrumentos musicais. Determinava o controle que se exercia sobre o ensino e prática musical dos jovens, que se manifestava em vários aspectos. Quanto ao tempo dedicado à aula de música, não devia se estender por mais de três anos (Pl. Leg. 7.810a). O professor não podia induzir o aluno ao virtuosismo, evitando a multiplicidade de sons sobre a lýra, a excessiva alternância entre pequenos e grandes intervalos, os sons rápidos e lentos, os tons agudos e graves, e, ainda, a variedade de ritmos no acompanhamento feito pela lýra. Enfim, o kitharistếs devia ensinar o jovem a colocar o instrumento a serviço da voz, não o estimulando a buscar a destreza técnica no instrumento (Pl. Leg. 7.812d). Afastam-se assim as práticas que visam ao profissionalismo, que fere a índole de liberdade do cidadão, pois o profissional se circunscreve no mundo da necessidade, da tekhné, do trabalho, do salário - e boa parte desses músicos profissionais, que com freqüência chega a fazer fortuna, é formada por estrangeiros, o que é um agravante em termos de julgamento moral sobre o ofício do músico profissional. A dignidade é propiciada pelo amadorismo na música - isto é, não se devem ensinar coisas difíceis ${ }^{18}$.

Toda esta preocupação para evitar que o ensino se voltasse ao profissionalismo, presente por exemplo na obra de Platão e Aristóteles, indica que, possivelmente, muitos professores de música pensassem de modo diferente: comprometidos com a qualidade da arte dedicada às Musas, inseridos no espírito de sua geração artística, é razoável que muitos entre os kitharistaí se dedicassem aos alunos mais talentosos, para torná-los capazes de realizar uma bela performance musical, executando peças do repertório da 'Nova Música', que se disseminou ao longo do século V, colocando mais

${ }^{18}$ BÉLIS, p. 18. 
dificuldades técnicas para o canto e para a execução de instrumentos. Contrariamente à ideologia política que impunha limites ao ensino musical, um kitharistếs renomado preferiria preparar seu aluno para a fama, para a profissão de músico. Sabe-se que o citarista Stratonicos, por exemplo, após instalar sua escola de música em Atenas, dispensava alunos pouco talentosos.

Platão considerava esse "modismo" das escolas atenienses, eventualmente levando ao virtuosismo exibicionista e profissionalizante, uma grave falha, pois o objetivo último do ensino musical não deveria ser formar o gosto estético das crianças, mas sim torná-las bons cidadãos e soldados. O bom exemplo era, para ele, Esparta, cujo repertório ensinado parece ter sido fixado no séc. VII e início do séc. VI. O conservadorismo do sistema de educação musical espartano compartilhava dos mesmos pressupostos de Damon e Platão de que mudar as formas da música acarretava alterar as leis da cidade, estando música, moral e política interligados (Pl. Leg. 7.800a, Arist. Pol. 4.3.1290a.23-28). ${ }^{19}$

Conclui-se que a idealização e institucionalização do ensino musical cumpria um papel fundamental para a concretização de um dos principais ideais da pólis: a kalo-kagathía, a formação do cidadão guiado pelos princípios articulados do bem e da beleza. O programa pedagógico musical da pólis grega, portanto, visava a fundir ética e estética.

\section{TitLE. Ethics and aesthetics in Greek music: education and the ideal of kalo-kagathía}

ABSTRACT. Ethics and esthetics are two absolutely connected dimensions of the Greek musical though. The moral principles enclosed, for instances, in the musical éthos theory lead the appreciation of the musical forms, either in the instruments choice, the musical genders or the musical modes (scales). The importance given by the Greeks to the connection between esthetics and ethics in music acquired political relevance, as one can verify in the prominence attributed to musical education. As one analyzes the biography of the most important Athenian public men, by studying the Lives by Plutarch, one testifies how deep the influence of musical building was valued, in shaping political and moral qualities of the citizens. One thought that music played an important role in the constitution of the virtue named kalo-kagathia (beauty-goodness), that one considered the highest well for a citizen: the acknowledgement of the beautifulness, and the choice of the good, the fair. One sees the existence of a political pedagogy, based in the notions of ethics and esthetics, in which the musical teaching deserved a lot of attention, as demonstrate the recommendations of Plato and Aristote.

Keywords. Ancient Greece; music; education; ethics; esthetics.

${ }^{19}$ E. Moutsopoulos, La musique dans l'oeuvre de Platon, Paris, 1959, p. 186-8. BéLis, p. 18. Cf. Damon fr. 14 (Lasserre). 